\title{
Cancer incidence and cancer mortality in a cohort of semiconductor workers
}

\author{
T SORAHAN, ' J A H WATERHOUSE,' M J MCKIERNAN, ${ }^{2}$ AND R H R ASTON ${ }^{2}$ \\ From the Cancer Epidemiology Research Unit, ${ }^{1}$ University of Birmingham, Edgbaston, Birmingham \\ B15 2TH, and Lucas Industries plc, ${ }^{2}$ Birmingham B19 $2 X F, U K$
}

ABSTRACT The cancer mortality experienced by a cohort of 1807 workers from a semiconductor factory during the period 1970-82 has been investigated (as has cancer morbidity for 1970-81). Expectations for mortality were calculated on the basis of rates of mortality for the general population of England and Wales. Expectations for cancer incidence were calculated on the basis of incidence rates for the West Midland Region. For the total study cohort, observed numbers of deaths and incident cases for all cancers were close to expectation. For melanoma incidence, an observed of 3 cases was compared with an expectation of 0.68 .

An analysis has been made of cancer incidence and cancer mortality among workers in a semiconductor factory.

\section{Methods}

\section{STUDY POPULATION}

Details of identification and employment history (name, address, date of birth, and dates of starting and ceasing work at the factory) were coded for 1807 past and present workforce employees (281 men and 1526 women). This workforce comprised a "census" population in employment on 1 January 1970 (759 employees) together with those who started employment between 1 January 1970 and 31 December 1979 (1048 employees). All had a minimum period of employment of one month.

Information was available only from 1970 onwards, which prevented the inclusion of those who had both entered and left employment before 1970. The composition of the study cohort by sex and year of starting employment is shown in table 1 and by sex and employment status in table 2 .

The National Health Service Central Register (NHSCR) of the Office of Population Censuses and Surveys (OPCS) provided information on the vital status of each individual on the closing date of the survey, 31 December 1982 (table 3). Insufficient information was available for tracing 56 workers by the NHSCR. Of these 56, three were still employed, 12 were "traced alive" by virtue of being on the current electoral register, and the remaining 41 were

Received 10 September 1984

Accepted 15 October 1984
Table 1 Study population by sex and year of starting employment

\begin{tabular}{lrrr}
\hline Year of starting employment & Men & Women & Total \\
\hline-1959 & 28 & 68 & 96 \\
$1960-9$ & 74 & 589 & 663 \\
$1970-4$ & 99 & 599 & 698 \\
$1975-9$ & 80 & 270 & 350 \\
Total & 281 & 1526 & 1807 \\
\hline
\end{tabular}

Table 2 Study population by sex and employment status

\begin{tabular}{lccr}
\hline & Men & Women & Total \\
\hline Left employment & 181 & 992 & 1173 \\
Still employed & 100 & 534 & 634 \\
Total & 281 & 1526 & 1807 \\
\hline
\end{tabular}

*As at 31 December 1982.

traced alive by the central offices of the Department of Health and Social Security (DHSS) at Newcastle. There is, therefore, a complete trace for this study population.

For those who had died, a death certificate was obtained with the underlying cause of death coded to the 8th revision of the ICD. Mortality was investigated for the period 1 January 1970 to 31 December 1982.

The OPCS also supplied details of cancer registrations from the National Cancer Registration Scheme. National registrations were complete to the end of 1980. Therefore, the main index files of the Birmingham and West Midlands Regional Cancer Registry (BRCR) were also searched for each of the employees in the study population for details of any tumours registered in 1981 . 
Table 3 Vital status of study population on closing date of study (31 December 1982)

\begin{tabular}{lr}
\hline Traced alive at Southport & 1697 \\
Traced alive at DHSS & 41 \\
Traced alive: electoral register & 12 \\
Traced alive: still employed & 3 \\
Emigrated & 2 \\
No trace & 0 \\
Deceased & 52 \\
Total & 1807 \\
\hline
\end{tabular}

Lists of suspected cases of cancer supplied by local shop stewards were also investigated.

\section{SMR APPROACH}

The mortality experience of the study cohort was compared with that which might have been expected to occur if rates of mortality for the general population of England and Wales had been operating on the study cohort, having due regard for the composition of the study cohort by age and sex and calendar year. Calculations were performed using the MANYEARS program. Observed and expected numbers of deaths were compared using the Poisson test of statistical significance (two tailed tests were used throughout).

Expectations for cancer morbidity for the period 1970-81 inclusive were calculated using incidence rates for the West Midlands Region for 1973-6.' (The region comprises Hereford and Worcester, Staffordshire, Shropshire, Warwickshire, and the West Midlands Metropolitan County.)

CASE-CONTROL APPROACH

For each cancer of interest, four controls were selected randomly from the study population, matching for sex, employment status (part time/full time), age at starting employment ( \pm 2 years), year of starting employment ( \pm 2 years), and duration of employment (at least equal to that of the case). Detailed job histories were obtained for the cases and controls.

The period from first employment until the diagnosis of cancer was calculated for each case. The exposure to any given process in this periodestimated as duration of employment in relevant departments- was then calculated for each case and for its matching controls. If the null hypothesis of no cancer effect from the process is true the probability that the case will have the highest exposure is one out of five $(0 \cdot 2)$. This expectation is compared with an observed of unity (if the case does in fact have the highest exposure) or zero (if the case does not have the highest exposure). Such contributions are summed over all relevant cases.

\section{Results}

MORTALITY-SMR APPROACH

Table 4 shows observed and expected numbers of deaths for principal causes by successive five year periods from first employment for men and women combined. The deficit for all causes in the total study population is statistically significant at the $5 \%$ level $(E=73.2, O=52$, SMR $=71, p<0.05)$. This deficit is likely to be due, at least in part, to selection effects: both the "healthy worker effect" and the "survivor population effect." There is some overall evidence of a healthy worker effect, with the SMRs

Cable 4 Mortality 1970-82, by years from furst employment (irrespective of how long any individual remains in the industry). Men and vomen

\begin{tabular}{|c|c|c|c|c|c|c|c|c|c|c|c|c|c|c|c|c|}
\hline \multirow{3}{*}{$\begin{array}{l}\text { Imployment } \\
\text { ntry } \\
\text { ohort }\end{array}$} & \multirow{3}{*}{$\begin{array}{l}\text { Cause of } \\
\text { death }\end{array}$} & \multicolumn{15}{|c|}{ Years from first employment } \\
\hline & & \multicolumn{3}{|l|}{$0-4$} & \multicolumn{3}{|l|}{$5-9$} & \multicolumn{3}{|c|}{$10-14$} & \multicolumn{3}{|l|}{$>15$} & \multicolumn{3}{|l|}{ Total } \\
\hline & & $E$ & $O$ & $S M R$ & $E$ & $O$ & $S M R$ & $E$ & $O$ & $S M R$ & $E$ & $O$ & $S M R$ & $E$ & $O$ & $S M R$ \\
\hline 're-1970 & $\begin{array}{l}\text { All cancers } \\
\text { DCS } \\
\text { DCR } \\
\text { Other causes } \\
\text { All causes }\end{array}$ & $\begin{array}{l}1 \cdot 6 \\
1 \cdot 4 \\
0 \cdot 3 \\
1 \cdot 2 \\
4 \cdot 5\end{array}$ & $\begin{array}{l}0 \\
1 \\
0 \\
2 \\
3\end{array}$ & $\begin{array}{l}(-) \\
(71) \\
(-) \\
(67)\end{array}$ & $\begin{array}{r}4 \cdot 1 \\
3.6 \\
0.9 \\
2.0 \\
10.6\end{array}$ & $\begin{array}{l}3 \\
1 \\
0 \\
0 \\
4\end{array}$ & 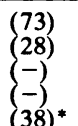 & $\begin{array}{r}5 \cdot 9 \\
5 \cdot 8 \\
1 \cdot 4 \\
2 \cdot 2 \\
15 \cdot 3\end{array}$ & $\begin{array}{r}7 \\
3 \\
0 \\
2 \\
12\end{array}$ & $\begin{array}{l}(119) \\
(52) \\
(-) \\
(91) \\
78)\end{array}$ & $\begin{array}{r}6.4 \\
8.5 \\
2 \cdot 0 \\
1.9 \\
18 \cdot 8\end{array}$ & $\begin{array}{r}9 \\
3 \\
2 \\
2 \\
16\end{array}$ & $\begin{array}{l}\left(\begin{array}{l}141) \\
35) \\
100) \\
(105)\end{array}\right. \\
(85)\end{array}$ & $\begin{array}{r}18 \cdot 0 \\
19 \cdot 3 \\
4 \cdot 6 \\
7 \cdot 4 \\
49 \cdot 2\end{array}$ & $\begin{array}{r}19 \\
8 \\
2 \\
6 \\
35\end{array}$ & $\begin{array}{l}(106) \\
(42) \\
44) \\
(81)\end{array}$ \\
\hline $970-9$ & $\begin{array}{l}\text { All cancers } \\
\text { DCS } \\
\text { DCR } \\
\text { Other causes } \\
\text { All causes }\end{array}$ & $\begin{array}{r}3.8 \\
3.0 \\
0.7 \\
2.6 \\
10.1\end{array}$ & $\begin{array}{l}5 \\
4 \\
2 \\
0 \\
1 \\
7\end{array}$ & $\begin{array}{l}(105) \\
(67) \\
(-) \\
(38)\end{array}$ & $\begin{array}{r}10.0 \\
4.6 \\
3.9 \\
0.9 \\
2.0 \\
11.4\end{array}$ & $\begin{array}{l}4 \\
2 \\
4 \\
0 \\
3 \\
9\end{array}$ & $\begin{array}{l}30) \\
(102) \\
(-) \\
(150)\end{array}$ & $\begin{array}{l}1.0 \\
0.9 \\
0 \cdot 2 \\
0 \cdot 4 \\
2.5\end{array}$ & $\begin{array}{r}12 \\
0 \\
0 \\
0 \\
1 \\
1\end{array}$ & $\begin{array}{l}(-) \\
(-) \\
(250) \\
40)\end{array}$ & & 10 & & $\begin{array}{r}49.2 \\
9.4 \\
7 \cdot 8 \\
1.8 \\
5.0 \\
24.0\end{array}$ & $\begin{array}{r}35 \\
6 \\
6 \\
0 \\
5\end{array}$ & $\begin{array}{l}(64) \\
(77) \\
-)\end{array}$ \\
\hline otal & $\begin{array}{l}\text { All cancers } \\
\text { DCS } \\
\text { DCR } \\
\text { Other causes } \\
\text { All causes }\end{array}$ & $\begin{array}{r}5.4 \\
4.4 \\
1.0 \\
3.8 \\
14.6\end{array}$ & $\begin{array}{r}4 \\
3 \\
0 \\
3 \\
10\end{array}$ & $\begin{array}{l}74) \\
(68) \\
(-) \\
(68)\end{array}$ & $\begin{array}{r}8.7 \\
7.5 \\
1.8 \\
4 \cdot 0 \\
22.0\end{array}$ & $\begin{array}{r}5 \\
5 \\
5 \\
0 \\
3 \\
13\end{array}$ & $\begin{array}{l}(57) \\
(67) \\
(7) \\
75) \\
59)\end{array}$ & $\begin{array}{r}6.9 \\
6.7 \\
1.6 \\
2.6 \\
17.8\end{array}$ & $\begin{array}{r}1 \\
7 \\
3 \\
0 \\
3 \\
13\end{array}$ & $\begin{array}{l}(101) \\
(45) \\
(-) \\
(115)\end{array}$ & $\begin{array}{r}6 \cdot 4 \\
8 \cdot 5 \\
2 \cdot 0 \\
1.9 \\
18 \cdot 8\end{array}$ & $\begin{array}{r}9 \\
3 \\
2 \\
2 \\
16\end{array}$ & $\begin{array}{l}(141) \\
(35) \\
100) \\
105) \\
(85)\end{array}$ & $\begin{array}{r}27 \cdot 4 \\
27 \cdot 1 \\
6 \cdot 4 \\
12 \cdot 3 \\
73 \cdot 2\end{array}$ & $\begin{array}{r}25 \\
14 \\
2 \\
11 \\
52\end{array}$ & $\begin{array}{l}(91) \\
52) \\
(31) \\
89 \\
71)^{*}\end{array}$ \\
\hline
\end{tabular}

$\mathrm{p}<0.05$.

ICS = Diseases of the circulatory system.

ICR $=$ Diseases of the respiratory system. 
Table 5 Cancer mortality 1970-82. Pre-1970 employment entry cohort

\begin{tabular}{|c|c|c|c|c|c|c|c|}
\hline \multirow[t]{2}{*}{ Site } & \multirow[t]{2}{*}{ ICD 8th } & \multicolumn{2}{|l|}{ Men } & \multicolumn{2}{|c|}{ Women } & \multicolumn{2}{|l|}{ Total } \\
\hline & & $E$ & $O(S M R)$ & $E$ & $O(S M R)$ & $E$ & $O(S M R)$ \\
\hline $\begin{array}{l}\text { Cancer of the: } \\
\text { Buccal cavity and throat } \\
\text { Digestive system } \\
\text { Respiratory system } \\
\text { Skin } \\
\text { Breast } \\
\text { Genitoürinary system } \\
\text { Reticuloendothelial system } \\
\text { Other cancers } \\
\text { All cancers }\end{array}$ & $\begin{array}{l}140-149 \\
150-157 \\
160-163 \\
172-173 \\
174 \\
180-189 \\
200-209 \\
140-209\end{array}$ & $\begin{array}{l}0.06 \\
1.39 \\
2.02 \\
0.04 \\
0.00 \\
0.50 \\
0.27 \\
0.40 \\
4.68\end{array}$ & $\begin{array}{l}0(-) \\
1(72) \\
3(149) \\
0(-) \\
0(-) \\
0(-) \\
2(741) \\
2(500) \\
8(171)\end{array}$ & $\begin{array}{r}0.15 \\
2.75 \\
1.86 \\
0.19 \\
3.83 \\
2.65 \\
0.76 \\
1.12 \\
13.31\end{array}$ & $\begin{array}{c}0(-\overrightarrow{)}) \\
4(145) \\
2(108) \\
1(526) \\
2(52) \\
1(38) \\
0(-() \\
1(89) \\
11(83)\end{array}$ & \begin{tabular}{r|}
0.21 \\
4.14 \\
3.88 \\
0.23 \\
3.83 \\
3.15 \\
1.03 \\
1.52 \\
17.99
\end{tabular} & $\begin{array}{c}0(-\overrightarrow{)}) \\
5(121) \\
5(129) \\
1(435) \\
2(52) \\
1(32) \\
2(194) \\
3(197) \\
19(106)\end{array}$ \\
\hline
\end{tabular}

Table 6 Cancer mortality 1970-82. Total study population

\begin{tabular}{|c|c|c|c|c|c|c|c|}
\hline \multirow[t]{2}{*}{ Site } & \multirow[t]{2}{*}{ ICD 8th } & \multicolumn{2}{|l|}{ Men } & \multicolumn{2}{|c|}{ Women } & \multicolumn{2}{|l|}{ Total } \\
\hline & & $E$ & $O(S M R)$ & $E$ & $O(S M R)$ & $E$ & $O(S M R)$ \\
\hline $\begin{array}{l}\text { Cancer of the: } \\
\text { Buccal cavity and throat } \\
\text { Digestive system } \\
\text { Respiratory system } \\
\text { Skin } \\
\text { Breast } \\
\text { Genitourinary system } \\
\text { Reticuloendothelial system } \\
\text { Other cancers } \\
\text { All cancers }\end{array}$ & $\begin{array}{l}140-149 \\
150-157 \\
160-163 \\
172-173 \\
174 \\
180-189 \\
200-209 \\
140-209\end{array}$ & $\begin{array}{l}0.10 \\
1.85 \\
2.70 \\
0.07 \\
0.00 \\
0.64 \\
0.42 \\
0.56 \\
6.34\end{array}$ & $\begin{array}{c}0(-) \\
2(108) \\
4(148) \\
0(-) \\
0(-) \\
0(-) \\
2(476) \\
3^{*}(536) \\
11(174)\end{array}$ & $\begin{array}{r}0.23 \\
4.12 \\
2.79 \\
0.33 \\
6.30 \\
4.21 \\
1.26 \\
1.77 \\
21.01\end{array}$ & $\begin{array}{c}0(-\overrightarrow{)}) \\
5(121) \\
3(108) \\
1(300) \\
2(32) \\
1(24) \\
1(79) \\
1(56) \\
14(67)\end{array}$ & $\begin{array}{r}0.33 \\
5.97 \\
5.49 \\
0.40 \\
6.30 \\
4.85 \\
1.68 \\
2.33 \\
27.35\end{array}$ & $\begin{array}{c}0(-) \\
7(117) \\
7(128) \\
1(250) \\
2(32) \\
1(21) \\
3(179) \\
4(172) \\
25(91)\end{array}$ \\
\hline
\end{tabular}

Table 7 Cancer morbidity 1970-81. Pre-1970 employment entry cohort

\begin{tabular}{|c|c|c|c|c|c|c|c|}
\hline \multirow[t]{2}{*}{ Site } & \multirow[t]{2}{*}{$I C D$ 8th } & \multicolumn{2}{|l|}{ Men } & \multicolumn{2}{|c|}{ Women } & \multicolumn{2}{|l|}{ Total } \\
\hline & & $E$ & $O(S R R)$ & $E$ & $O(S R R)$ & $E$ & $O(S R R)$ \\
\hline $\begin{array}{l}\text { Cancer of the: } \\
\text { Buccal cavity and throat } \\
\text { Digestive system } \\
\text { Respiratory system } \\
\text { Skin } \\
\text { Breast } \\
\text { Genitourinary system } \\
\text { Reticuloendothelial system } \\
\text { Other and unspecified cancers } \\
\text { All cancers } \\
\text { All sites excluding other } \\
\text { skin (173) }\end{array}$ & $\begin{array}{l}140-149 \\
150-157 \\
160-163 \\
172-173 \\
174 \\
180-189 \\
200-209 \\
140-209\end{array}$ & $\begin{array}{l}0.14 \\
1.67 \\
2.24 \\
0.07 \\
0.01 \\
0.93 \\
0.34 \\
0.42 \\
6.45\end{array}$ & $\begin{array}{c}0(-) \\
2(120) \\
3(134) \\
0(-) \\
0(-) \\
0(-) \\
2(588) \\
3^{*}(714) \\
10(155)\end{array}$ & $\begin{array}{r}0.40 \\
3.58 \\
1.63 \\
2.23 \\
7.84 \\
5.35 \\
1.01 \\
1.90 \\
23.94\end{array}$ & $\begin{array}{c}0(-\overrightarrow{)}) \\
4(112) \\
1(61) \\
6(269) \\
9(115) \\
3(56) \\
1(99) \\
3(158) \\
27(113)\end{array}$ & $\begin{array}{r}0.54 \\
5.37 \\
3.87 \\
2.93 \\
7.85 \\
6.28 \\
1.35 \\
2.32 \\
30.39\end{array}$ & $\begin{array}{l}0(-) \\
6(114) \\
4(103) \\
6(205) \\
9(115) \\
3(48) \\
3(222) \\
6(259) \\
37(122)\end{array}$ \\
\hline
\end{tabular}

*p $<0.05$.

$S \hat{R R}=$ Standardised registration ratio $=(\mathrm{O} / \mathrm{E}) \times 100$.

for all causes in the first two periods from first employment $(0-4$ years, $S M R=68 ; 5-9$ years, $S M R=$ 59) being lower than those found for the two later periods $(10-14$ years, $S M R=73 ;>15$ years, $S M R$ $=85)$.

Observed and expected numbers of deaths from cancer for the main site groupings are shown for the pre-1970 employment entry cohort-that is, those already employed on 1 January 1970 - and for the total study population in tables 5 and 6 respectively. Overall, the observed number of deaths from cancer was close to expectation $(E=27 \cdot 35, O=$ $25)$. The only difference between sex specific and cause specific observed and expected numbers that was statistically significant was that found for "other and unspecitied cancers" in men $(E=0.56, O=3$, $\mathrm{p}<0.05)$.

\section{CANCER MORBIDITY}

Table 7 shows observed and expected numbers of cancer registrations for the main site groupings for the pre-1970 employment entry cohort and table 8 these for the total study population. For all employees, the observed number is close to expectation for all cancers $(E=47 \cdot 74, O=49)$. There is a deficit for women and an excess for men. Neither 
Table 8 Cancer morbidity 1970-81. Total study population

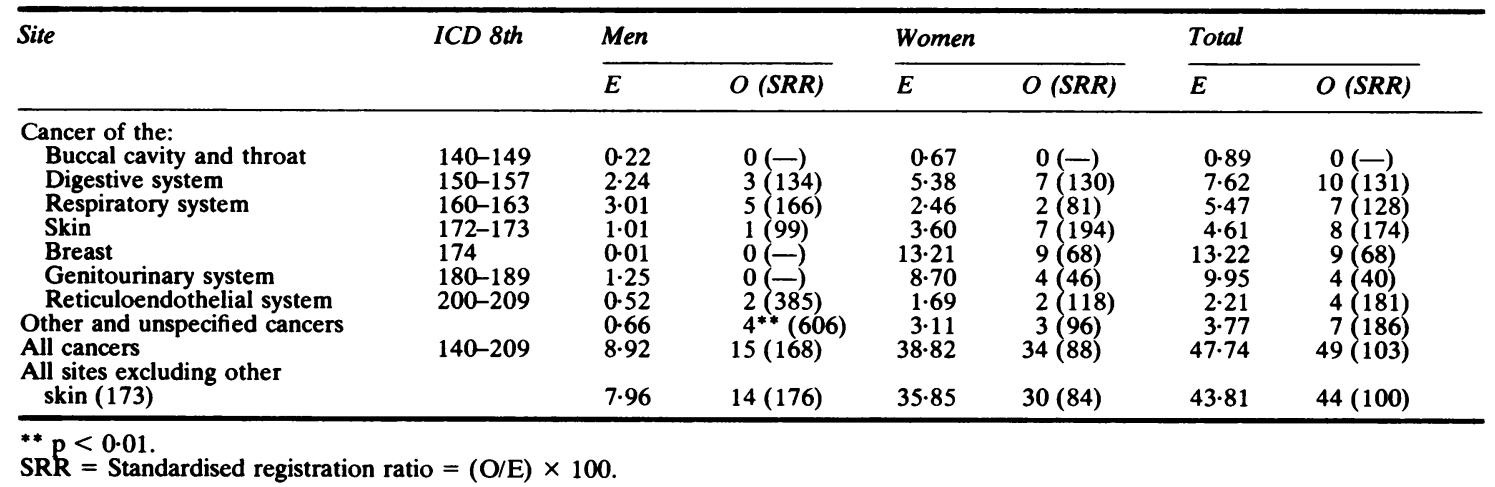

result is, however, statistically significant.

For all employees there was an excess incidence of melanoma ( $E=0.68, O=3$ ), a finding that is not statistically significant at the $5 \%$ level for a two tailed test (statistically significant at the 5\% level for a one tailed test, $p=0.03$ ). All three cases occurred in women. The incidence of other skin tumours is close to expectation $(E=3 \cdot 93, O=5)$. The excess incidence from all skin cancers is not statistically significant $(E=4 \cdot 61, O=8)$.

An expectation for melanoma incidence was also calculated using age specific and sex specific cancer registration rates for England and Wales. Rates for 1971 were used for the period 1970-1, annual rates were used for 1972-7, and rates for 1978 were used for 1978-81. The resulting overall expectation was $0 \cdot 85$. Annual cancer registration rates almost certainly continued to increase during 1978-81, and the "correct" expectation (on the basis of national rates) is likely to be at least 0.90 . The difference between an expectation of 0.85 or 0.90 and an observed of three cases is not statistically significant.

There is an excess incidence among men for "other and unspecified" cancers $(E=0.66, \mathrm{O}=4)$, a finding that is statistically significant at the $1 \%$ level. These four cancers were registered as unknown primaries.

It follows from these tables that there are deficits for cancers of the breast $(E=5 \cdot 37, O=0)$ and for all cancers $(E=13 \cdot 79, O=6)$ among women in the 1970-9 employment entry cohort, findings which are statistically significant at the $5 \%$ level.

CASE-CONTROL APPROACH

Testing the null hypothesis of no effect from occupational exposure to ultraviolet light on the risk of incidence of melanoma

As ultraviolet light is probably a risk factor for melanomas, and as it is used in one process at the plant (photomasking in the clean room), the above seemed an important hypothesis to test (even though occupational exposure may be low compared with non-occupational exposure).

Table 9 shows the durations of employment in the photomasking process for cases of melanoma and for controls. One case has a longer duration of employment in the photomasking process than any of its controls. This is to be compared with an expectation of 0.6 and is clearly not statistically significant.

Testing the null hypothesis of no effect from duration of employment at the plant on risk of incidence of melanomas

A case-control approach can only supply information on "risk" factors when a proportion of subjects have experienced the risk (as was true in the above instance). Thus if all possible cases and controls have been uniformly exposed to a particular hazard, a case-control approach cannot be informative. To elucidate whether general occupational exposure may have been a factor in the observed incidence of

Table 9 Occupational exposure to ultraviolet * light for cases of melanoma and controls $\dagger$

\begin{tabular}{llll}
\hline $\begin{array}{l}\text { Case } \\
\text { No }\end{array}$ & $\begin{array}{l}\text { Occupational } \\
\text { exposure to UV } \\
\text { light }^{*}\end{array}$ & Controlst & $\begin{array}{l}\text { Occupational } \\
\text { exposure to } U V \\
\text { light }\end{array}$ \\
\hline 1 & 2.0 & 1 & 0.0 \\
& & 2 & 0.0 \\
& & 3 & 0.0 \\
& 0.0 & 4 & 0.0 \\
& & 1 & 0.0 \\
3 & 0.0 & 2 & 0.0 \\
& & 3 & 1.6 \\
& & 1 & 0.0 \\
& & 2 & 1.5 \\
& & 3 & 0.0 \\
& & 4 & 0.0 \\
\hline
\end{tabular}

*Estimated as duration of employment in photomasking process (years).

† Matching for sex, employment status (part time/full time), year of starting employment, age at starting employment, and duration of employment. 
skin cancer, a separate set of controls was selected for each case without matching for "duration of employment." The cases and controls were then compared with respect to duration of employment. No significant differences were found.

\section{Discussion}

The nature of the study population places limitations on the power of this study. In many instances of occupatonal carcinogenesis there are long latent periods, and the lack of available data for those workers who both entered and left employment before 1970 has made this study less informative than it might have been.

For the total study cohort, mortality and morbidity from all cancers were close to expectation. The level of statistical significance quoted for the incidence of melanomas may, however, be misleading, because it refers to the probability of finding such a result by chance alone if the study population is selected without prior knowledge of its cancer morbidity (selected randomly), whereas this population was studied because astute observers had noted several instances of skin cancers among the workers. Such considerations have no bearing on the question of whether or not occupational exposures have influenced the development of any or all of the melanomas observed, only that the attachment of a level of statistical significance to the result is made more difficult.

In 1983 Vagero and Olin published a study of the risk of cancer morbidity among workers in the Swedish electronics industry compared with that in the general working population. ${ }^{2}$ They noted an increased risk for "tumour sites connected with the pharynx and the respiratory system." Such an effect was not found in this study (ICD 8:140-149, E = $0 \cdot 89, \mathrm{O}=0$; ICD 8:160-163, $\mathrm{E}=5 \cdot 47, \mathrm{O}=7$ ). Nevertheless, as the authors point out "the electronics industry contains several occupations and different working environments."

\section{References}

' Waterhouse J, Muir C, Shanmugaratnam K, Powell J, eds. Cancer incidence in five continents. Lyon: International Agency for Research on Cancer, 1982. (IARC Scientific publication No 42.)

2 Vagero D, Olin R. Incidence of cancer in the electronics industry: using the new Swedish cancer environment registry as a screening instrument. Br J Ind Med 1983;40:188-92. 